\title{
Manajemen Kendaraan Ground Handling di Terminal 1 Bandara Internasional Juanda
}

\author{
Hendra Annisa Putri Lintang Hestuningrum ${ }^{1, *}$, Ervina Ahyudanari ${ }^{1}$ \\ Departemen Teknik Sipil, Institut Teknologi Sepuluh Nopember, Surabaya ${ }^{1}$ \\ Koresponden*, Email: hendrannisa@gmail.com
}

\begin{tabular}{ll}
\hline \multicolumn{1}{c}{ Info Artikel } & Abstract \\
\hline Diajukan 28 Juli 2018 & This paper discusses the issue of ground handling, namely the handling of aircraft when on \\
Diperbaiki 05 Oktober 2018 & land, from the plane it blocks on to block off. Furthermore, this ground handling serves \\
Disetujui 17 Oktober 2018 & baggage, passengers and aircraft services when on land. The calculation method is based on \\
the following data: maximum service time, average transfer time at existing conditions, and & total time remaining for each type of vehicle in 2015. After calculation, it is known that the \\
estimated number of each type of ground handling vehicle in Terminal 1 Juanda & International Airport in 2020 , and in 2025. The results include: passangers boarding stairs 5 \\
in the year 2020 and 9 in the year $2025 ;$ belt loaders 20 in the year 2020 and 44 in the year \\
2025; baggage carts for unloading 5 vehicles in the year 2020 and 7 in the year $2025 ;$ \\
baggage carts for loading 5 vehicles in the year 2020 and 20 in the year $2025 ;$ catering 9 \\
vehicles in the year 2020 and 24 in the year 2025; Lavatory service and fuel truck 10 vehicles \\
in the year 2020 and 29 in the year 2025; and ground power units 21 vehicles in the year \\
Keywords: Ground handling, GSE,
\end{tabular}

\begin{abstract}
Abstrak
Makalah ini membahas perihal ground handling, yakni penanganan pesawat pada saat berada di darat, dari pesawat itu blok on hingga blok off. Lebih lanjut, ground handling ini melayani bagasi, penumpang, dan pelayanan pesawat saat di darat. Metode perhitungan didasarkan pada data waktu pelayanan maksimum, rata-rata waktu perpindahan pada kondisi eksisting, dan total waktu sisa setiap jenis kendaraan pada tahun 2015. Setelah dilakukan perhitungan maka diketahui perkiraan jumlah setiap jenis kendaraan ground handling di Terminal 1 Bandara Internasional Juanda di tahun 2020, dan tahun 2025. Hasil yang diperoleh meliputi: passangers boarding stairs 5 kendaraan pada tahun 2020 dan 9 pada tahun 2025; belt loader 20 kendaraan pada tahun 2020 dan 44 pada tahun 2025; baggage carts untuk unloading 5 kendaraan pada tahun 2020 dan 7 pada tahun 2025; baggage carts untuk loading 5 kendaraan pada tahun 2020 dan 20 pada tahun 2025; kendaraan catering 9 kendaraan pada tahun 2020 dan 24 pada tahun 2025; kendaraan lavatory service and fuel truck 10 kendaraan pada tahun 2020 dan 29 ada tahun 2025; dan untuk ground power units 21 kendaraan pada tahun 2020 dan 37pada tahun 2025.
\end{abstract}

pelayanan pesawat saat di apron oleh Ground Support Equipment (GSE) (Majid dan Warpani 2009).

Ada dua cara penanganan pesawat di bandara udara yaitu turnaround arrangement dan transit arrangrement. turnaround arrangement adalah penanganan bagi pesawat yang mendarat di tujuan akhir sedangkan transit arrangrement adalah penanganan bagi pesawat yang mendarat di kota persinggahan atau transit. Penanganan pesawat di Bandar udara baik transit arrangrement dan turnaround arrangement menganut system yang sama hanya perbedaan terletak pada lama waktu penanganannya pada transit arrangrement lama waktunya lebih singkat karena tidak berubah crew dan penumpang turun di ruang transit sedangkan turnaround arrangement biasanya memerlukan waktu 40 menit hingga 1 jam (Majid dan Warpani 2009). 
Ground handling adalah penanganan pesawat pada saat berada di darat atau apron bandara, dari pesawat itu blok on hingga blok off. Ground handling ini melayani bagasi, penumpang, dan pelayanan pesawat saat didarat seperti kargo, ramp series yang berupa parkir, toilet, pengisian air bersih, pembersihan, bahan bakar, chatering, menarik pesawat hingga apron dan lain lain. Pelayanan pesawat tersebut dinamakan ground support equipment (GSE). GSE ini memiliki banyak persyaratan mengenai waktu dan kecepatan saat kendaraan tersebut berada di apron. Kecepatan, akurasi dan efisiensi sangat penting untuk pelayanan ground handling. Di Bandara - bandara Indonesia terdapat berbagai perusahaan yang menangani Ground handling, seperti Gapura, JAS, Lion dan masih banyak lagi.

Permasalahan delay menimbulkan kerugian yang besar. Dampak dari adanya delay tidak hanya merugikan satu pihak saja, melainkan beberapa pihak yang terkait. Delay tentunya merugikan penumpang, pihak maskapai, bahkan sampai dengan kru pesawat yang bertugas. Bagi penumpang, delay berakibat pada waktu tunggu penumpang, pergantian jadwal penerbangan, sampai pembatalan penerbangan. Bagi pihak maskapai, delay berakibat pada kepuasan penumpang, pemberian kompensasi penumpang, biaya pemeliharaan, biaya kru dan pemborosan avtur. Untuk pesawat Boeing 777, apabila terjadi delay selama 1 jam dapat menghabiskan avtur sebesar 1,7 ton. Tidak hanya itu saja, penundaan jadwal keberangkatan dan kedatangan pesawat menimbulkan efek berkesinambungan untuk penerbangan berikutnya karena dipastikan akan merembet ke semua rute yang terkait (Pudjobroto, 2014). Bahan bakar pesawat, ground handling serta biaya sangat berkaitan, tak hanya proses ground handling yang diperhatikan, peraturan mengenai lingkungan yang berkaitan dengan konsumsi bahan bakar juga diperhatikan [1]

Delay akibat dari penanganan ground handling seperti pada penelitian hersanti pada tahun 2015 pada hari minggu 1 Nopember 2015 terdapat 111 penerbangan turnaround namun yang ontime dalam melakukan proses ground handling hanya 25 penerbangan saja penerbangan lainnya terjadi keterlambatan dalam proses ground handling hingga persentase dari keterlambatan hingga $77,48 \%$ yang mana ini sangat mempengaruhi penerbangan selanjutnya.

Karena jumlah penumpang dan pergerakan pesawat baik komersial atau militer selalu meningkat setiap tahunnya, yang secara tidak langsung pergerakan kendaraan ground handling juga meningkat dalam melayani pesawat satu dan yang lainnya. Apabila satu kendaraan ground handling terlambat maka akan mempengaruhi kegiatan kendaraan ground handling lainnya.

Berdasarkan sejarah perkembangan perusahaan ground handling di Indonesia, munculnya perusahaan ground handling bermula dari adanya kegiatan perpindahan bandara internasional Kemayoran ke Halim Perdana Kusuma. Sambil menunggu selesainya pembangunan bandara baru Soekarno-Hatta yang lebih modern di Cengkareng Jakarta (waktu itu), pada saat bersamaan Garuda Indonesia yang kala itu juga berperan sebagai penyedia jasa ground handling bagi penerbangan asing. Pada saat itu jasa pelayanan ground handling sangat berkembang maka pada tanggal 8 Juni 1984 berdirilah PT. Jasa Angkasa Semesta sebagai "second ground handling company" mendampingi Garuda Indonesia (Majid dan Warpani 2009). Dinegara tertentu ada peraturan baru mengenai maskapai berhak memilih perusahaan ground handling mana yang akan melayani maskapainya, hal ini akan menjadikan persaingan dalam perusahaan ground handling seperti Bandara Schiphol di Amsterdam [2]

Keberhasilan tugas ground handling ini berkaitan dengan banyak hal, diantaranya adalah kuantitas dan kualitas sumber daya manusia, peralatan, dan prosedur standar operasi yang digunakan. [3]. Standart pelayanan ground handling telah diatur oleh International Air Transport Association yang disingkat IATA dalam Aircraft Handling Manual (AHM) 8102013 mengenai standart ground handling agreement. Dimana setiap kegiatan dan setiap kendaraan harus melakukan sesuai dengan AHM 810 2013.

Robbin Stall tahun 2008 meneliti mengenai penanganan ground handling dimasa yang akan datang. Dengan cara memperpendek critical path pada setiap jenis pesawat. Critical path di perpendek dengan cara pada kegiatan catering dengan konsep menambah pekerja, kendaraan cetering menggabungkan security check dan cabin check dapat mengurangi waktu pelayanan hingga 20\%(Robbin Stall, 2008).

Delay sebuah pesawat disebabkan oleh berbagai macam masalah, pelayanan ground handling salah satunya. Delay yang diakibatkan oleh ground handling ini terjadi tergantung dengan waktu pelayanan masing-masing kendaraan ground handling. Seperti pada bandara Internasional Juanda pada hari minggu tanggal 1 Nopember 2015 terdapat 111 penerbangan turnaround yang pelayanan ground handling - nya ontime hanya 25 penerbangan saja, penerbangan lainnya mengalami keterlambatan 2 menit hingga 147 menit dengan rata - rata keterlambatan 22 menit[4]. 
Kendaraan - kendaraan ground handling tersebut memiliki waktu yang berbeda - beda dalam melayani pesawat tergantung dengan besar pesawat dan jumlah bagasi dan kargo yang dibawa oleh pesawat tersebut. Seperti studi terdahulu untuk tipe pesawa Boeing 737 membutuhkan waktu selama 45 menit dan untuk pesawat A320-2035 membutuhkan waktu 30 menit [5],[6]. Waktu kritis adalah waktu terpendek dan waktu terpanjang dari proses ground handling. Waktu kritis dalam pelayanan ground handling ini untuk memprediksi waktu total pekerjaan dan waktu terpanjang yang memiliki kesalahan paling kecil. Biasanya waktu kritis terjadi pada bagian pengisian bahan bakar, naik turun penumpang dan kegiatan cabin service dan catering [7]. Tujuan dari penelitian ini adalah mendapatkan perkiraan jumlah kendaraan ground handling pada tahun 2020 dan 2025

\section{Metode}

Untuk mendapatkan jumlah kendaraan ground handling pada tahun 2020 dan 2025 digunakan data pergerakan tahunan yang didapat dari PT. Angkasa Pura I dan data pergerakan harian yang diambil dari data Rahayu (2015) yang mana pada data tersebut terdapat pergerakan pesawat saat turnaround. Dari data-data tersebut ditentukan peak hour dan data pesawat saat peak hour yang akan digunakan sebagai acuan jumlah pergerakan pesawat pada tahun 2020 dan 2025 dengan menggunakan regresi.

Jumlah perkiraan kebutuhan kendaraan ground handling dihitung menggunakan waktu pelayanan maksimum, ratarata waktu perpindahan dan total waktu sisa dari setiap jenis kendaraan ground handling yang melayani pesawat saat peak hour, data ini didapat dari perhitungan sebelumnya. Dengan membandingkan antara total waktu sisa dan penjumlahan antara waktu pelayanan maksimum dan ratarata waktu perjalanan serta jumlah pergerakan pesawat didapatkan jumlah perkiraan kebutuhan kendaraan ground handling tahun 2020 dan 2025.

\section{Hasil dan Pembahasan}

\subsection{Pergerakan Pesawat}

Jumlah pergerakan pesawat tahunan yang diambil dari PT. Angkasa Pura I dapat dilihat pada Gambar 1. Data tersebut digunakan untuk peramalan jumlah pergerakan tahun 2020 dan 2025. Pada penelitian sebelumnya diketahui jumlah penerbangan pesawat pada saat turnaround di tanggal 11 Nopember 2015 adalah 111 penerbangan [4].

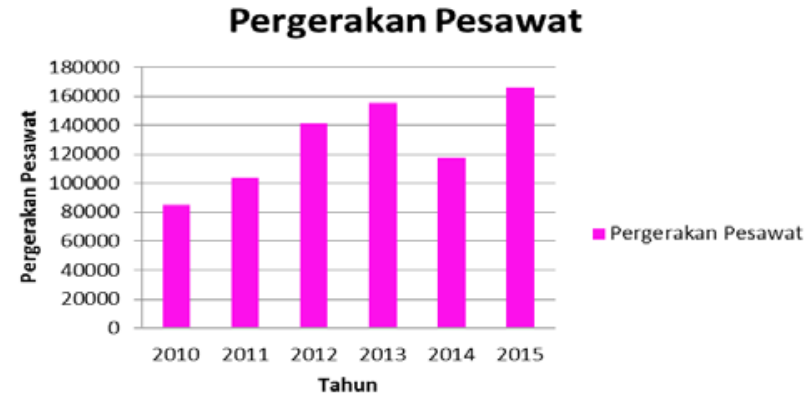

Gambar 1. Pergerakan pesawat tahunan Sumber: PT Angkasa Pura I

Penerbangan turnaround adalah penerbangan secara langsung. Dari penerbangan tersebut didapat peak hour pada pukul 11.00 - 11.59 dengan 21 pergerakan pesawat seperti data pada Gambar 2 yang terdiri dari tipe-tipe pesawat dapat dilihat pada Gambar 3.

Dari pergerakan dan penerbangan tersebut jumlah pergerakan pesawat saat peak hour pada tahun 2020 dan 2025 didapatkan dengan menggunakan regresi 6 tahun terakhir yaitu tahun 2010 hingga 2015. Setelah dilakukan peramalan dengan berbagai regresi yang dapat dilihat pada Tabel 1, hasil peramalan yang mendekati pada data adalah regresi exponensial. Sehingga dengan regresi exponensial didapatkan hasil peramalan pergerakan pesawat seperti pada Tabel 2 dan Gambar 2.

\section{Jumlah Pergerakan Setiap Tipe Pesawat}

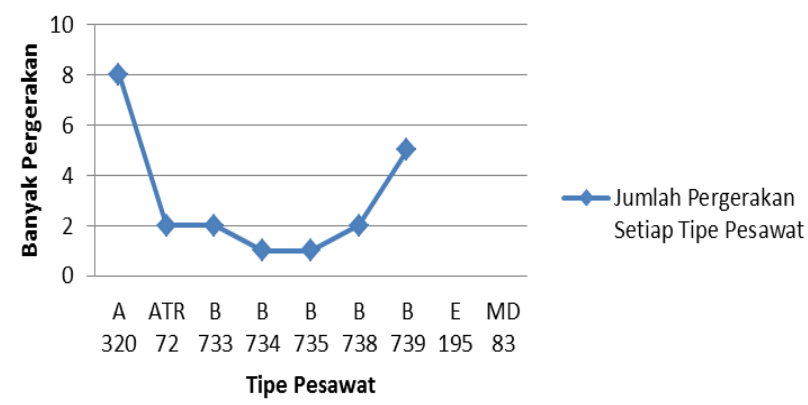

Gambar 2. Pergerakan pesawat turnaround pada tanggal 11 Nopember 2015 


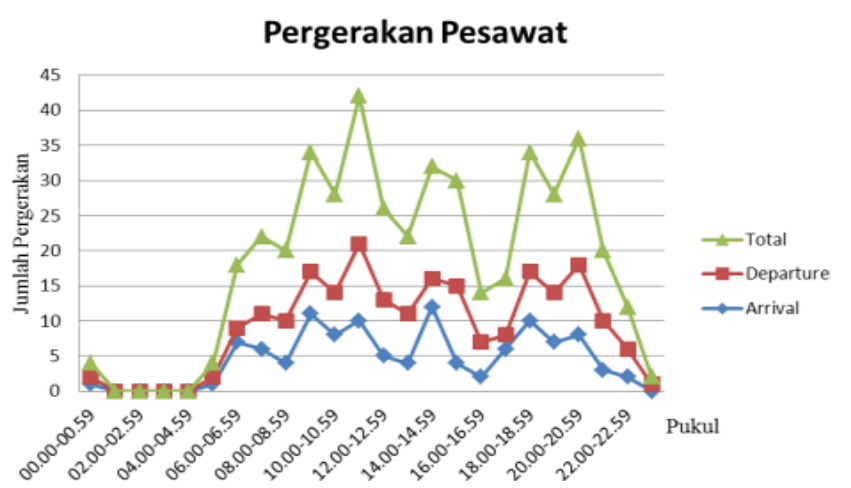

Gambar 3. Jumlah pergerakan pesawat setiap tipe pesawat

Gambar 3 menunjukkan garis regresi exponensial dengan rumus regresi $\mathrm{y}=85898 e^{0,1057 x}$, rumus ini digunakan untuk memperkirakan jumlah pergerakan pesawat tahun 2020 dan 2025. Dengan rumus tersebut didapatkan jumlah pergerakan pesawat tahun 2020 adalah 274.750 pergerakan dan tahun 2025 adalah 466.082 pergerakan. Dari hasil peramalan pergerakan pesawat tersebut didapatkan jumlah penerbangan turnaround 1 hari dengan cara mengalikan presentase terhadap total pergerakan pesawat tahunan di seperti pada Tabel 2 . Pergerakan harian 0,0016\% dari pergerakan tahunan dan pergerakan turnaround 0,83\% dari pergerakan harian

Tabel 1. Perbandingan regresi

\begin{tabular}{lc}
\hline \multicolumn{1}{c}{ Regresi } & Hasil Peramalan untuk Tahun 2015 \\
\hline Exponensial & 160.580 \\
Power & 151.997 \\
Linier & 155.876 \\
Polynomial & 87.657 \\
Logaritmik & 148.884 \\
\hline
\end{tabular}

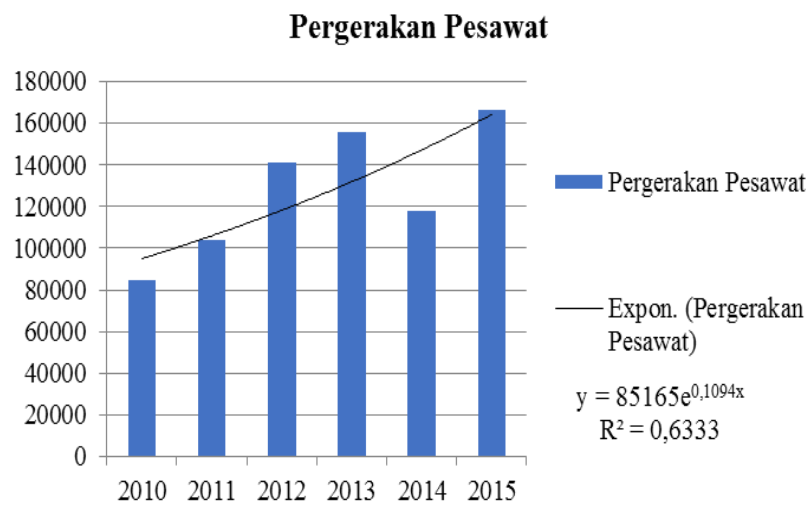

Gambar 4. Grafik regresi pergerakan pesawat
Tabel 2. Perkiraan pergerakan pesawat harian pada tahun 2020 dan 2025

\begin{tabular}{cccc}
\hline Tahun & $\begin{array}{c}\text { Jumlah Pergerakan } \\
\text { Tahunan }\end{array}$ & $\begin{array}{c}\text { Pergerakan } \\
\text { Harian }\end{array}$ & $\begin{array}{c}\text { Pergerakan } \\
\text { Turnaround }\end{array}$ \\
\hline 2015 & 166.208 & 266 & 222 \\
2020 & 274.750 & 440 & 367 \\
2025 & 466.082 & 746 & 623 \\
\hline
\end{tabular}

Data pergerakan setiap tipe pesawat dapat dilihat pada Tabel 3, yang didapatkan dengan perkalian antara persentase terhadap total pergerakan dengan jumlah pergerakan turnaround pada Tabel 2.

Tabel 3. Perkiraan pergerakan setiap tipe pesawat tahun 2020 dan 2025

\begin{tabular}{cccc}
$\begin{array}{l}\text { Tipe } \\
\text { Pesawat }\end{array}$ & $\begin{array}{c}\text { Presentase terhadap } \\
\text { pergerakan turnaround }\end{array}$ & $\begin{array}{c}\text { Tahun } \\
2020\end{array}$ & $\begin{array}{c}\text { Tahun } \\
2025\end{array}$ \\
\hline A 320 & 0,297 & 109 & 185 \\
ATR 72 & 0,081 & 30 & 50 \\
B 733 & 0,054 & 20 & 34 \\
B 734 & 0,009 & 3 & 6 \\
B 735 & 0,018 & 7 & 11 \\
B 738 & 0,126 & 46 & 79 \\
B 739 & 0,387 & 142 & 241 \\
E 195 & 0,018 & 7 & 11 \\
MD 83 & 0,009 & 3 & 6 \\
\hline
\end{tabular}

Data perkiraan pergerakan saat peak hour pada Tabel 4 didapat dengan mengalikan presentase terhadap pergerakan harian dengan total pergerakan harian yang terdapat pada Tabel 3.

Tabel 4. Perkiraan pergerakan saat peak hour tahun 2020 dan 2025

\begin{tabular}{|c|c|c|c|}
\hline $\begin{array}{c}\text { Tipe } \\
\text { Pesawat }\end{array}$ & $\begin{array}{c}\text { Presentase terhadap } \\
\text { pergerakan harian }\end{array}$ & $\begin{array}{c}\text { Tahun } \\
2020\end{array}$ & $\begin{array}{c}\text { Tahun } \\
2025\end{array}$ \\
\hline A 320 & 0,12 & 22 & 13 \\
\hline ATR 72 & 0,11 & 6 & 3 \\
\hline В 733 & 0,17 & 6 & 3 \\
\hline В 734 & 0,50 & 3 & 2 \\
\hline В 735 & 0,25 & 3 & 2 \\
\hline В 738 & 0,07 & 6 & 3 \\
\hline В 739 & 0,06 & 14 & 8 \\
\hline E 195 & 0,00 & 0 & 0 \\
\hline MD 83 & 0,00 & 0 & 0 \\
\hline \multicolumn{2}{|r|}{ Total } & 35 & 59 \\
\hline
\end{tabular}




\subsection{Perkiraan Jumlah Kendaraan Ground Handling Tahun 2020 dan 2025}

Dengan data pada Tabel 1 didapatkan waktu pelayanan maksimal, waktu rata-rata perpindahan kendaraan dan waktu sisa total dari setiap jenis kendaraan ground handling pada tahun eksisting yang diringkas pada Tabel 5.

Tabel 5. Hasil perhitungan jumlah kendaraan tahun 2015

\begin{tabular}{lcccc}
\hline \multicolumn{1}{c}{ Jenis } & $\begin{array}{c}\text { Jumlah } \\
\text { Kendaraan } \\
\text { Tahun 2015 }\end{array}$ & $\begin{array}{c}\text { Waktu } \\
\text { Pelayanan } \\
\text { Maks }\end{array}$ & $\begin{array}{c}\text { Rerata } \\
\text { Waktu } \\
\text { Pindah }\end{array}$ & $\begin{array}{c}\text { Total } \\
\text { Waktu } \\
\text { Sisa }\end{array}$ \\
\hline $\begin{array}{l}\text { Passangers } \\
\text { Boarding }\end{array}$ & 2 & 60,9 & 1,5 & 52,7 \\
$\begin{array}{l}\text { Stairs } \\
\text { Belt Loader }\end{array}$ & 9 & 52,7 & 1,0 & 132,0 \\
$\begin{array}{l}\text { Baggage } \\
\text { Cart }\end{array}$ & 5 & 28,3 & 1,0 & 417,2 \\
$\begin{array}{l}\text { Loading } \\
\text { Baggage }\end{array}$ & 5 & 17,2 & 1,0 & 379,3 \\
$\begin{array}{l}\text { Cart } \\
\text { Unloading }\end{array}$ & 5 & 22,0 & 1,4 & 204,2 \\
$\begin{array}{l}\text { Kendaraan } \\
\text { Catering }\end{array}$ & 5 & 29,7 & 1,0 & 234,0 \\
$\begin{array}{l}\text { Fuel Truck } \\
\text { Ground }\end{array}$ & 6 & 57,6 & 1,1 & 144,5 \\
$\begin{array}{l}\text { Power Units } \\
\text { Lavatory }\end{array}$ & 10 & 26,7 & 1,0 & 254,8 \\
Service & 5 & & & \\
\hline
\end{tabular}

Waktu sisa pada Tabel 5 adalah waktu setiap kendaraan menunggu melayani pesawat selanjutnya. Rata-rata waktu pindah adalah rata-rata setiap kendaraan pada setiap jenis kendaraan ground handling berpindah menuju gate selanjutnya untuk melayani pesawat, dan waktu pelayanan maksimum adalah waktu pelayanan setiap jenis kendaraan ground handling melayani pesawat sesuai dengan fungsi masing-masing jenis kendaran.

Data pada Tabel 5 dapat memperkirakan jumlah kendaraan ground handling tahun 2015 yang telah dihitung memenuhi atau tidak untuk melayani pesawat pada peak hour tahun 2020 dan 2025. Dengan membandingkan waktu sisa dan penjumlahan antara waktu pindah dan waktu pelayanan perkiraan jumlah kendaraan ground handling didapatkan. Dengan perbandingan tersebut jumlah dari perhitungan tahun 2015 untuk passangers boarding stair dengan 2 unit dan dengan waktu sisa yang ada tidak lagi dapat melayani pesawat selanjutnya maka harus ditambah kebutuhannya, belt loader dengan 9 unit dapat melayani hingga 24 pergerakan pesawat, untuk baggage cart untuk loading/unloading dengan 5 unit dapat melayani hingga 36 pergerakan pesawat untuk loading dan 43 pergerakan pesawat untuk baggage cart untuk unloading. Untuk kendaraan catering dengan 5 unit dapat melayani hingga 30 pergerakan, fuel truck dengan 6 unit dapat melayani hingga 29 pergerakan, ground power units dengan 10 unit dapat melayani hingga 23 pergerakan dan untuk lavatory service dengan 5 unit dapat melayani hingga 30 pergerakan.

Untuk jumlah pergerakan diatas data tersebut, maka digunakan regresi untuk setiap jenis kendaraan ground handling, regresi yang dipilih adalah regresi polynomial, dimana regresi ini memiliki $R^{2}$ yang paling tinggi dari regresi lainnya. Rumus untuk mendapatkan perkiraan jumlah kebutuhan kendaraan ground handling terdapat pada Tabel 6. Jumlah perkiraan kebutuhan kendaraan ground handling tahun 2020 dan 2025 didapat dari rumus regresi yang terdapat pada Tabel 6 dapat dilihat pada Tabel 7.

Tabel 6. Rumus perkiraan jumlah kebutuhan untuk setiap jenis kendaraan ground handling

\begin{tabular}{|c|c|c|}
\hline $\begin{array}{c}\text { Jenis } \\
\text { Kendaraan }\end{array}$ & $R^{2}$ & Rumus \\
\hline Passangers & & \\
\hline $\begin{array}{l}\text { Boarding } \\
\text { Stairs }\end{array}$ & 0,9096 & $y=0,038 x^{2}+0,2715 x+1,6088$ \\
\hline $\begin{array}{l}\text { Belt Loader } \\
\text { Baggage }\end{array}$ & 0,9894 & $y=0,0061 x^{2}+0,7179 x+7,5125$ \\
\hline $\begin{array}{l}\text { Cart } \\
\text { Loading }\end{array}$ & 0,9867 & $y=0,0145 x^{2}-0,1335 x+4,9396$ \\
\hline $\begin{array}{l}\text { Baggage } \\
\text { Cart } \\
\text { Unloading }\end{array}$ & 0,7701 & $y=0,0032 x^{2}-0,0677 x+5,2355$ \\
\hline $\begin{array}{l}\text { Kendaraan } \\
\text { Catering }\end{array}$ & 0,9894 & $y=0071 x^{2}-0,2857 x+3,1839$ \\
\hline $\begin{array}{l}\text { Fuel Truck } \\
\text { Ground }\end{array}$ & 0,9855 & $y=0,00127 x^{2}+0,1575 x+4,9379$ \\
\hline $\begin{array}{l}\text { Power } \\
\text { Units }\end{array}$ & 0,9986 & $y=-0,0002 x^{2}+0,7638 x+8,3785$ \\
\hline $\begin{array}{l}\text { Lavatory } \\
\text { Service }\end{array}$ & 0,9871 & $y=0,0137 x^{2}+0,1491 x+3,8013$ \\
\hline
\end{tabular}

Tabel 7. Perkiraan jumlah kebutuhan kendaraan ground handling tahun 2020 dan 2025

\begin{tabular}{lcc}
\hline \multicolumn{1}{r}{ Jenis Kendaraan } & Tahun & Tahun \\
& 2020 & 2025 \\
\hline Passangers Boarding Stairs & 5 & 9 \\
Belt Loader & 20 & 44 \\
Baggage Cart Loading & 5 & 20 \\
Baggage Cart Unloading & 5 & 7 \\
Kendaraan Catering & 9 & 24 \\
Fuel Truck & 10 & 29 \\
Ground Power Units & 21 & 37 \\
Lavatory Service & 10 & 29 \\
\hline
\end{tabular}




\section{Kesimpulan}

Dengan perhitungan jumlah kebutuhan kendaraan ground handling tahun 2015 sebagai acuan, dan dengan membandingkan antara total waktu sisa dan penjumlahan antara rata-rata waktu pindah dan waktu pelayanan didapatkan perkiraan jumlah kendaraan ground handling tahun 2020 dan 2025 adalah sebagai berikut:

- Passangers boarding stairs 5 kendaraan pada tahun 2020 dan 9 kendaraan pada tahun 2025.

- $\quad$ Belt loader 20 kendaraan pada tahun 2020 dan 44 kendaraan pada tahun 2025,

- Baggage carts untuk unloading 5 kendaraan pada tahun 2020 dan 7 kendaraan pada tahun 2025,

- Baggage carts untuk loading 5 kendaraan pada tahun 2020 dan 20 kendaraan pada tahun 2025,

- $\quad K e n d a r a a n$ catering 9 kendaraan pada tahun 2020 dan 24 kendaraan pada tahun 2025,

- $\quad$ Kendaraan Lavatory service 10 kendaraan pada tahun 2020 dan 29 kendaraan pada tahun 2025,

- Fuel truck 10 kendaraan pada tahun 2020 dan 29 kendaraan pada tahun 2025,

- Dan untuk ground power units 21 kendaraan pada tahun 2020 dan 37 kendaraan pada tahun 2025.

\section{Daftar Pustaka}

[1] M. Weiszer, J. Chen, and G. Locatelli, “An integrated optimisation approach to airport ground operations to foster sustainability in the aviation sector q,” Appl. Energy, vol. 157, pp. 567-582, 2015.

[2] G. Burghouwt, J. Poort, and H. Ritsema, "Lessons learnt from the market for air freight ground handling at amsterdam airport schiphol,” J. Air Transp. Manag., vol. 41, pp. 56-63, 2014.

[3] Susanti, "Kajian Human Factor SDM Ground Handling di Bandar Udara Adi Sucipto Yogyakarta," War. ARDHIA J. Perhub. Udar. Kaji., pp. 29-42, 2016.

[4] H. Rahayu and E. Ahyudanari, "Evaluasi Kinerja Gate Assignment pada Terminal 1 Keberangkatan Domestik Bandar Udara Internasional Juanda Surabaya,” vol. 4, no. 1, pp. 2-7, 2015.

[5] M. Schmidt, A. Paul, M. Cole, and K. O. Ploetner, "Challenges for ground operations arising from aircraft concepts using alternative energy," J. Air Transp. Manag., vol. 56, no. Part B, pp. 107-117, 2016.

[6] P. García Ansola, J. De Las Morenas, A. García, and J. Otamendi, "Distributed decision support system for airport ground handling management using WSN and MAS,” Eng. Appl. Artif. Intell., vol. 25, no. 3, pp. 544-553, 2012.

[7] M. Schmidt, "A review of aircraft turnaround operations and simulations,” Prog. Aerosp. Sci., vol. 92, no. January, pp. 25-38, 2017. 